\title{
PSYCHE
}

\begin{tabular}{lll}
\hline Vol. 68 & December, 196r & No. 4 \\
\hline
\end{tabular}

\section{AUSTRALIAN CARABID BEETLES VII. TRICHOSTERNUS, ESPECIALLY THE TROPICAL SPECIES}

\author{
By P. J. Darlington, Jr. \\ Museum of Comparative Zoology, Cambridge, Mass.
}

This is one of a series of papers describing new Carabidae of zoogeographic importance referred to in my account ( $196 \mathrm{Ib}$ ) of transition of Australian wet forest carabid faunas. Some other papers of the series, including a list of my localities, are referred to below (p. I30). The present paper is concerned with Trichosternus, especially with the comparatively little known tropical species. Types of new species are placed, at least for the time being, in the Museum of Comparative Zoology; paratypes, with C.S.I.R. O. at Canberra and usually in the Queensland Museum. Proportions given in the descriptions are calculated from actual measurements.

Items of geographic or evolutionary interest derived from Trichosternus are its total distribution; the occurrence of two very distinct. (relict or primitive?) species, fax and montorum, high on Mt. Bartle Frere (one reaching Mt. Bellenden Ker too); the distribution of $T$. frater and its apparent allies (subvirens and simplicipes of South Queensland and nudipes to fisheri in the tropics), which form a group of mostly allopatric forms in which the male front tarsi have apparently been simplified in two different stocks and in which double invasion or hybridization may have occurred in a very limited area on part of the Atherton Tableland (pp. I22-125). Another case of hybridization (of eungella and mixtus) may have occurred on the Eungella Range (p. 127). See map for distribution of species on and north of the Atherton Tableland.

I cannot give an exclusive definition of Trichosternus. Characters used by Sloane (1894 etc.) and Tschitschérine (1902) fail among recently discovered species. Compared with Nurus, Trichosternus is usually smaller, more lightly built, with $\sigma^{t}$ front tarsi usually dilated and with 3 segments squamulose below, while in Nurus the $\sigma^{x}$ front tarsi are usually simple, rarely (e.g. in N. atlas Cast.) slightly dilated and with 2 segments squamulose. However, exceptional Trichosternus 


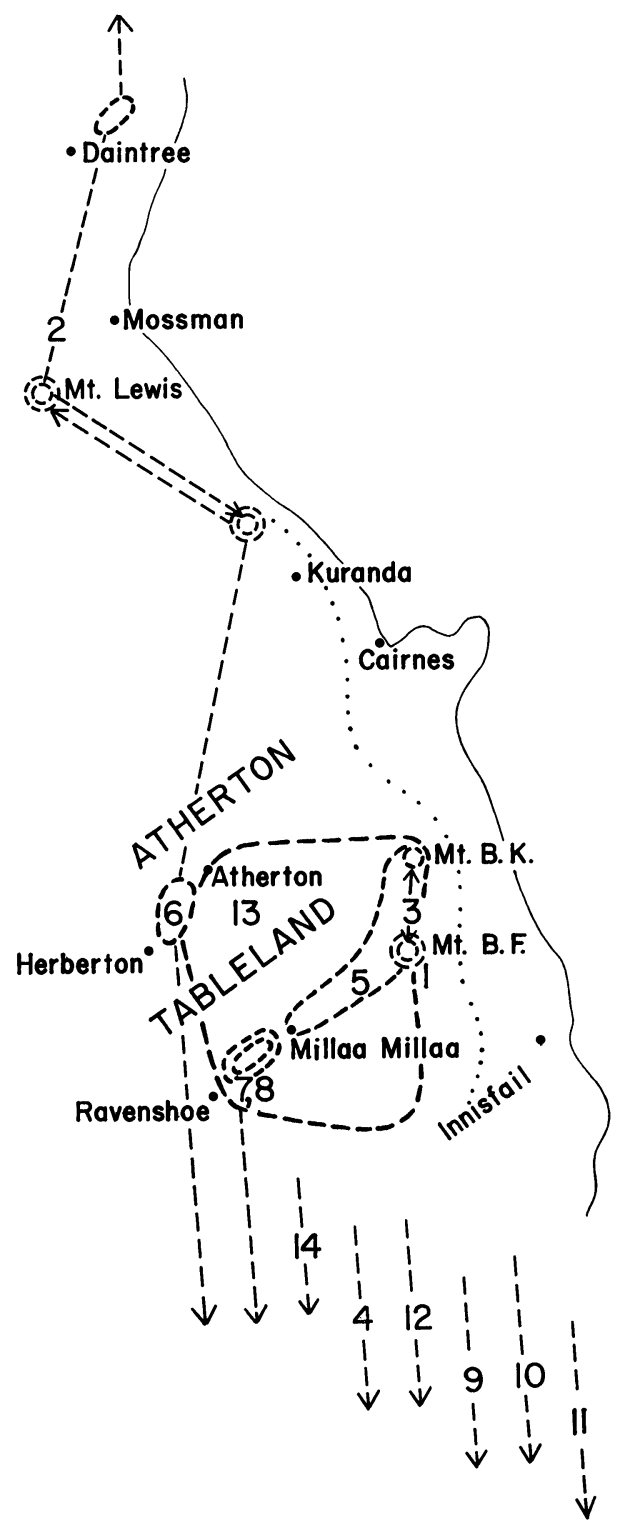

DARLINGTON - TrichOSTERNUS 
resemble Nurus in having $0^{\top}$ tarsi simple (T. subvirens Chd., simplicipes Sl., nudipes Darl., soror Darl.) or with only 2 segments squamulose (setosiceps Sl.). Compared with Notonomus, Trichosternus is usually larger, often with prosternal process setose (rarely in Notonomus), often with alternate intervals of elytra raised, and often without distinct Ioth intervals at outer edges of elytra, but all these characters fail in some species. A generic revision of the larger Australian pterostichines is much needed. The Australian genera should be compared with the New Zealand ones (Britton 1940) and phylogenies should be worked out if possible, and the old types, many of them in Europe, should be re-examined. However, I cannot undertake all this now.

The known range of T'richosternus is the eastern edge of Australia from the base of the Cape York peninsula (south of Cooktown) to central New South Wales (perhaps a little north of Sydney), with one species isolated in southwestern Australia (Darlington 1953) and another on New Caledonia. All the tropical Australian species (except cordatus) live in rain forest, but some more-southern species occur in savannah woodland, and some enter or are confined to south temperate rain forest on the Dorrigo-Ebor and Mt. Royal plateaus.

Before considering the tropical Trichosternus, I give the following tentative key to species south of the tropics, as a basis for comparison (cf. Sloane's key, I899, pp. 567-569, and Tschitschérine's, I902, pp.

\section{Explanation of Plate 7}

Known distribution of Trichosternus in tropical Queensland. The finely dotted line is the approximate eastern edge of high land (Atherton Tableland etc.). Arrows indicate occurrence southward, at increasing distances beyond the limits of the map, of the species indicated. The species are numbered in the order in which they are treated in the text. No. 1, on Mt. $\mathrm{B}$ (artle) $\mathrm{F}$ (rere), is Trichosternus fax; 2, obscuripennis, which extends north beyond the limits of the map nearly to Cooktown; 3, montorum; 4, nudipes, on the Mt. Spec plateau; 5, soror; 6, frater, which occurs north to Mt. Lewis and south beyond the limits of the map on the Kirrama Range; 7, mutatus; 8, fisheri; 9, eungella, and 10, mixtus, both on the Eungella Range; 11, cordatus, at the southern edge of the tropics; 12, spec, on the Mt. Spec plateau; 13 , setosiceps, which is widely distributed on the south-central Atherton Tableland and occurs also south of the limits of the map on the Kirrama Range; and 14, kirrama, on the Kirrama Range. Nos. 1, 2, 3, 13, 14 are very distinct, phylogenetically isolated species. Nos. 4, 5, 6, 7, 8 are apparently interrelated, chiefly allopatric members of the frater group (see text). Nos. 9, 10, both on the Eungella Range, though structurally distinct, may be related to each other and may hybridize (see text). No. 11 represents a primarily south temperate rather than tropical stock. No. 12, on the Mt. Spec plateau north of Townsville, is apparently related to another south temperate (New South Wales) species. 
523-530). I have specimens of all the 16 full species named in this key except cyaneotinctus.

Tentative key to Trichosternus of eastern Australia south of tropics

I. Elytral intervals 3, 5, 7 with seta-bearing punctures (Mt. Royal Range and highest part of Dorrigo-Ebor plateau; 2 species?)

australicus Sl.

- Only 3rd interval (if any) with seta-bearing punctures on elytral disc

2. Mesosternum setose anteriorly …………… ......................... 3

- Mesosternum not setose anteriorly ....................................... 7

3. Male front tarsi not dilated, not squamulose …………............. 4

- Male front tarsi dilated, 3 segments squamulose below ……… 5

4. Alternate discal elytral intervals scarcely differentiated; greenish (extreme SE. Q. \& adjacent N.S. W. border) .... subvirens Chd.

- Alternate discal intervals slightly elevated; black or nearly so, with cupreous or greenish margins (Bunya Mts., S. Q.) simplicipes Sl.

5. Seventh elytral intervals sharply carinate at base; prothorax relatively broad at base; length $c .22 \mathrm{~mm}$. (extreme NE. N. S. W. and adjacent $\mathrm{Q}$. border) angulosus Chd.

- Seventh intervals roundly costate at base 6

6. Very large, $c$. 33-40 mm. (SE. Q. to Blackall and Bunya Mts. etc.) renardi Chd.

- Not so large, $c .25-32 \mathrm{~mm}$. (N. S. W. S. to Dorrigo, Williams River, Booral, etc., and N. to Stanthorpe-Dalveen area, S.Q.) vigorsi Gory

7. Three supra-ocular setae each side ………............................. 8

- Two supra-ocular setae each side ............................................ 9

8. Purplish (savannah woodlands of N. N.S.W. chiefly west of the rain forest zone) superbus Cast.

- Greenish (unknown to me; may be another savannah woodland species) cyaneotinctus Boisd. incl. atroviridis S1.

9. Additional lateral prothoracic setae present (savannah woodland and drier rain forest of S.Q., N. into edge of tropics; probably includes hecate Tsch.) cordatus Chd.

- Only usual 2 pairs lateral prothoracic setae present ................ IO

Io. Very large, $34 \mathrm{~mm}$. or more …….................................... I I

- Smaller, $34 \mathrm{~mm}$. (maximum size of cyaneus only) or less ...... I 2

I I. Prosternal process setose; black; length 37-42 $\mathrm{mm}$. (extreme NE. N.S. W. and adjacent Q. border) perator Sl. 
- Prosternal process not setose; purplish; length 34-39 mm. (Blackall Range, SE. Q.) …………............. porphyriacus Sl.

I2. Posterior-lateral prothoracic setae near base .... at least 3 species: wilsoni Cast., nitidicollis Cast., and speciosus S1.

- Posterior-lateral prothoracic setae about $\mathrm{I} / 8$ of prothoracic length before base

13. Smaller, length $c .2 \mathrm{I}-27 \mathrm{~mm}$.; black sometimes slightly bluish or purplish (widely distributed in NE. N.S.W. and S. Q., from Dorrigo to Blackall Range ........................... marginiferus Chd.

- Larger, length c. 28-34 mm.; wholly purple or blue (Mt. Royal Range, Dorrigo, etc.; possibly 2 species) ................ cyaneus Cast.

The following key to tropical Australian Trichosternus differs from the preceding key in form (ranges and authorities omitted) because the tropical species are discussed individually. All the species have rather long, strong, curved mandibles; rather short, irregular, subparallel frontal foveae; well developed, emarginate mentum tooth; palpi not strikingly modified; elytra margined at base; 8th (submarginal) stria lined with very small ocellate punctures; lower surface impunctate or nearly so except for usual "fixed" punctures; and (so far as my observations go) other usual characters of the genus, except as otherwise stated.

\section{Key to Species of Trichosternus of Tropical Australia}

I. Mesosternum setose anteriorly; dorsal elytral intervals equal or nearly so (except in montorum)

- Mesosternum not setose anteriorly; alternate elytral intervals elevated (except scarcely so in kirrama)

2. Seventh intervals of elytra not sharply carinate at base (at most somewhat swollen); elytra without dorsal punctures

- Seventh intervals sharply carinate at base; elytra with (small) dorsal punctures

3. Subparallel, prothorax quadrate; humeri subdentate; color bluepurple

- Elytra oval, prothorax subcordate; humeri not dentate; black, elytra dull obscuripennis

4. Elytra with alternate intervals moderately raised; (form depressed; color greenish or bluish) montorum

- Elytra with discal intervals equal or nearly so, except at extreme base (frater group)

5. Male front tarsi not dilated, without squamules

- Male front tarsi more or less dilated, always with some squa- 
mules below

6. Broader; greenish nudipes

- Narrower; bluish or purplish soror

7. Greenish frater

- Black or purplish 8

8. Black or faintly purple ; smaller ( $18-20 \mathrm{~mm}$.) mutatus

- Purple; larger (23-25 mm.) fisheri

9. Only 2 pairs supra-ocular and 2 pairs lateral prothoracic setae (but extra apical ventral setae) present eungella

- Extra supra-ocular and/or lateral prothoracic setae present .... IO

IO. Prosternal process setose; if prosternal setae broken or not visible, note 3 supra-ocular and 4 or more median-lateral prothoracic setae each side, and odd elytral intervals costate ............. mixtus

- Prosternal process not setose ......... .............................. I I

I I. Only 2 pairs supra-ocular setae present, and odd elytral intervals raised I.2

- Extra supra-ocular setae present, or odd elytral intervals (except 7 th) scarcely raised and humeri scarcely dentate cordatus

I2. Black spec

- Purple 3

13. Only I pair median-lateral prothoracic setae present; odd elytral intervals costate setosiceps

- Extra lateral prothoracic setae present; odd elytral intervals (except 7 th) not costate kirrama

Trichosternus fax new species

Form as figured (Fig. I), subparallel, not strongly convex; black, head slightly metallic, pronotum with green or blụish marginal channels and copper-purple on disc brightest in baso-lateral areas, elytra with marginal channels blue or greenish blue; pronotum shining, head and elytra slightly duller. Head $c .3 / 4$ or slightly more width prothorax; eyes moderate, genae $c$. wide as eyes, rounded and somewhat narrowed to neck; antennae rather short (in genus), passing base of prothorax by $\mathrm{I}$ or 2 segments; 2 supra-ocular setae each side. Prothorax subquadrate, $c$. I/3 wider than long at middle, not much narrowed behind; base $c$. I/IO or more wider than apex (variable); apex broadly emarginate but angles not otherwise advanced, not margined; base subtruncate, slightly emarginate at middle, strongly margined at sides; sides weakly arcuate for much of length, broadly, slightly sinuate before $c$. right, well defined posterior angles; lateral margins narrow, slightly wider posteriorly, each with a seta about I/3 from apex and on margin at basal angle; disc rather flat, middle 

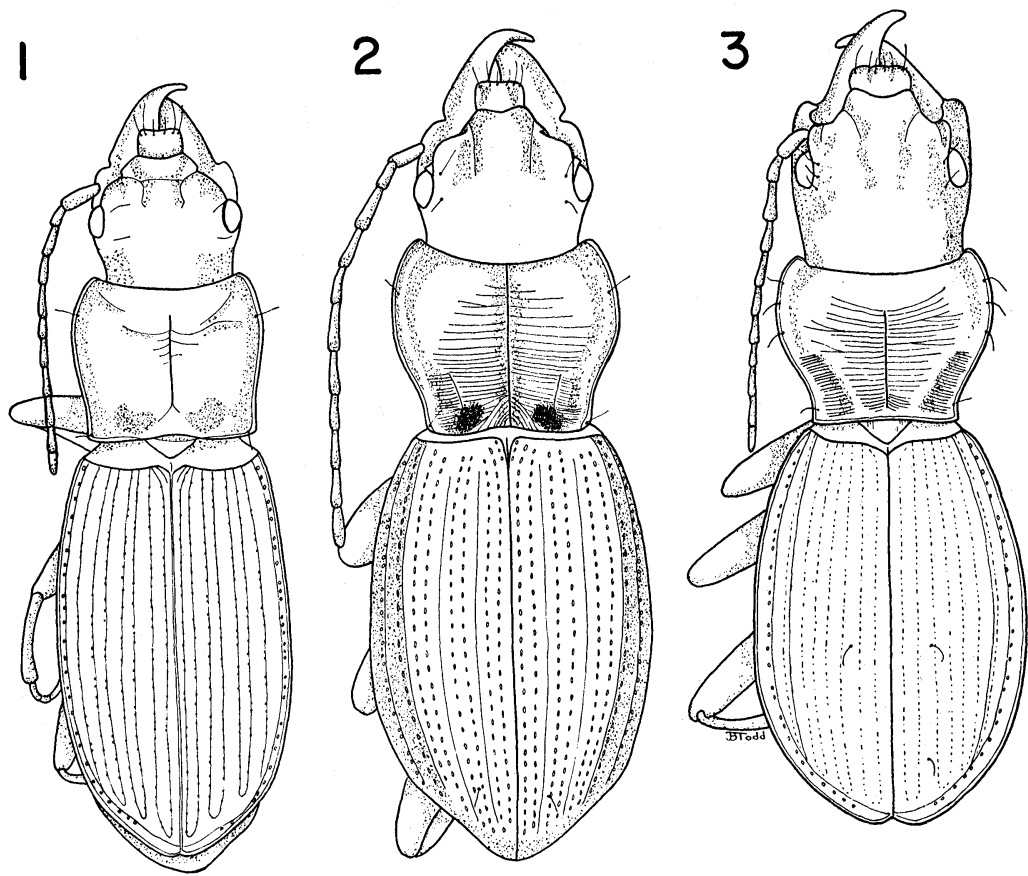

Fig. 1. Trichosternus fax n. sp. Fig. 2. T. montorum n. sp. Fig. 3. T. kirrama n. sp.

line deep, transverse impressions almost obsolete except for subbasal foveae each side midway between middle and sides, separated from margins by strong convexities; disc and foveae not punctate. Elytra c. I/5 wider than prothorax, usually slightly narrowed anteriorly; margin rectangular or almost acute at subdentate humeri; elytra with striae well impressed and punctate; intervals slightly convex but not costate, 3,5 , and 7 slightly wider than others but not more elevated, except 7 th slightly elevated at base; narrow Ioth interval indicated posteriorly; dorsal punctures lacking. Mesosternum anteriorly and prosternal process setose. Male front tarsi slightly dilated, 3 segments squamulose; $\sigma^{x}$ with $\mathrm{I}$, \& 2 setae each side last ventral segment. Length 20-23; width $6.5-7.7 \mathrm{~mm}$.

Holotype $\sigma^{\pi}$ (M.C.Z. Type No. 30,355) and I5 paratypes all from Mt. Bartle Frere, North Queensland, west slope 3000-5000 ft. (not found lower), Dec. 1957, collected by my wife, my son, and myself, in mountain rain forest. 
This new species is sufficiently distinguished from others in the preceding key. It is not closely related to any other known species. It may prove to be generically distinct from Trichosternus, or it may be a relict of the ancestral stock of the genus.

\section{Trichosternus obscuripennis (Macl.)}

This is the northernmost Trichosternus, and it descends to relatively low altitudes. Macleay ( 1887, p. 22O) described it from the Mossman River. Sloane had it from Helenvale south of Cooktown. I have it from Mt. Finnigan south of Cooktown, Thornton Peak near Daintree, Mt. Lewis near Mossman, and Black Mt. about 20 miles north of Kuranda. Although most of my specimens were taken at 2000 or $3000 \mathrm{ft}$. altitude, several were found at or below $1000 \mathrm{ft}$. in strips of rain forest along the trail between Thornton Peak and the Daintree River.

$T$. obscuripennis is a very distinct species but hardly a separate subgenus. Its lack of humeral teeth is approached in T. kirrama, and lack of dorsal elytral punctures is matched by $f a x$, although neither of these species is close to obscuripennis in other ways.

\section{Trichosternus montorum new species}

Form as figured (Fig. 2), rather broad, depressed; black with bluish, purplish, or sometimes greenish reflections, head and pronotal disc moderately shining, elytra a little duller. Head about $4 / 5$ width prothorax; eyes rather small, genae as wide or wider than eyes, irregularly arcuate and somewhat narrowed to neck; antennae rather long (in genus); 2 supra-ocular setae each side. Prothorax cordate; $1 / 3$ $( \pm)$ wider than long at middle; base slightly $( \pm \mathrm{I} / \mathrm{IO})$ narrower than apex; sides rounded for about $3 / 4$ of length, then rather strongly sinuate before $c$. right, scarcely blunted posterior angles; side margins moderate, not much wider basally, each with a seta about I/3 from apex and on margin at basal angle; apex not margined, broadly emarginate but angles not otherwise advanced; base broadly emarginate at middle, slightly rounded toward sides, vaguely margined at sides but not at middle; disc depressed, middle line deep, transverse impressions weak; baso-lateral foveae elongate but not strictly linear, slightly nearer margins than middle, not quite reaching middle of length, densely transversely rugulose, the rugulose areas meeting at middle posteriorly, with middle of base longitudinally rugulose; disc otherwise impunctate. Elytra oval, usually slightly narrowed anteriorly; margin somewhat obtusely angulate and finely toothed at humeri; elytra with finely punctate discal striae; intervals more or less convex, 3, 5, 7 increasingly elevated, 7 th being sharply carinate for 
most of length (most strongly so near base); Ioth interval indicated but not well developed; each 3 rd interval with 0 , I, or 2 dorsal punctures behind middle (often asymmetrical in number and position). Mesosternum anteriorly and prosternal process setose. Male front tarsi slightly dilated, 3 segments squamulose below; $0^{x}$ with I, 우 2 setae each side last ventral segment. Length 23.5-27; width 7.9-9.I $\mathrm{mm}$.

Holotype $\sigma^{\pi}$ (M.C.Z. Type No. 30,356) and 39 paratypes all from west slope Mt. Bartle Frere, North Queensland, 3000-5000 ft. (none lower), Dec. 1957, collected by the Darlingtons, in mountain rain forest. Also 6, not types, from east side Mt. Bellenden Ker, 3000-4500 ft., Dec. 1957, taken by myself, in mountain rain forest.

This seems to be a typical, rather generalized (primitive?) Trichosternus, without known close relatives. It is of course distinguished from other species in the preceding key.

\section{Trichosternus nudipes new species}

Form about average; greenish black, the green most distinct at sides and baso-lateral areas of pronotum and marginal channels of elytra; head and pronotum shining, elytra duller. Head c. 3/4 (by measurement) width prothorax; eyes small but abrupt, genae $c$. wide as eyes, convex, somewhat narrowed to neck; antennae of moderate length; 2 supra-ocular setae each side. Prothorax subcordate, moderately narrowed at base, $c . \mathrm{I} / 3( \pm)$ wider than long at middle; base slightly (less than I/IO) wider than apex; apex broadly emarginate with angles (lateral channels) slightly advanced, not margined; base broadly emarginate at middle, slightly rounded laterally, margined laterally; sides broadly rounded for much of length, moderately sinuate near $c$. right or slightly obtuse, scarcely blunted basal angles; lateral margins narrow, not wider basally, each with $I$ or sometimes 2 setae each side $\mathrm{I} / 3$ or less from apex and I seta on margin at basal angle; disc not very convex, middle line fine, transverse impressions weak; baso-lateral impressions deep, $c$. I/3 length prothorax, separated from lateral margins by convexities but extending inward somewhat vaguely nearly to middle; disc of pronotum impunctate except base irregularly rugulose. Elytra I/3 or less wider than prothorax, suboval, slightly narrowed anteriorly ; margins forming $c$. right or slightly obtuse, finely raised-dentate angles at humeri; dorsal striae very fine, finely punctate; each elytron with 7 (including suture) rather weak but almost entire costae, 7 th carinate basally; Ioth interval indicated toward apex; 3 rd interval usually 2-punctate, the punctures at or before apical I/3 and near apex, but individual punctures some- 
times absent or obscured. Mesosternum anteriorly and prosternal process (sometimes slightly) setose. Male front tarsi narrow, without squamules; $\sigma^{t}$ with $\mathrm{I}$,, 2 setae each side last ventral segment. Length 22.5-26; width 7.9-9.5 mm.

Holotype $\sigma^{\pi}$ (M. C.Z. Type No. 30,357) and 87 paratypes all from Mt. Spec plateau (Paluma Range), c. 40 miles north of Townsville, North Queensland, 2000-3000 ft., Dec. 1957 and Feb. 1958, taken by the Darlingtons, in rain forest; and I, same locality, June 7IO, I955, E. O. Wilson.

This is similar to and perhaps related to T. subvirens Chd. of South Queensland, but subvirens has an entire mentum tooth (emarginate in nudipes), posterior lateral pronotal setae just inside (not on) the margin, and lacks or nearly lacks rugulose sculpture on the base of the pronotum.

\section{Trichosternus soror Darl.}

I described this species (1953) from 3 specimens from Millaa Millaa, on the Atherton Tableland. I did not find it at this locality during my last trip, but found it on both the lower and upper western slopes of Mt. Bartle Frere, at 2000-3500 and 3000-5000 ft., and on the east side of Mt. Bellenden Ker, at 3000-4500 ft.

Although this small, bluish species has simplified male tarsi, like the preceding species, it may not be directly related to it but may be independently derived from a common ancestor perhaps resembling frater (below).

\section{Trichosternus frater new species}

Slightly more slender than average of genus, rather convex; greenish or bluish black, head and pronotum moderately shining, elytra somewhat duller. Head $4 / 5$ or more width prothorax; eyes small, genae about wide as eyes, rounded and somewhat narrowed to neck; 2 supra-ocular setae each side; antennae of moderate length. Prothorax subcordate, $c$. I/4 wider than long at middle; base slightly narrower than apex; apex broadly emarginate but angles otherwise scarcely advanced, apex not margined; base emarginate at middle, rounded toward sides, margined at sides; sides broadly arcuate through much of length, moderately sinuate toward base; basal angles $c$. right or slightly obtuse, scarcely blunted; side margins rather narrow; not much wider posteriorly, each with I seta near or before anterior I/3 and $\mathrm{I}$ on margin at basal angle; disc with distinct middle line, less distinct transverse impressions, and moderate baso-lateral foveae which reach posterior margin but are separated from lateral margins by convexities; surface of disc nearly smooth except with some (variable) 
transverse strigulation in baso-lateral impressions. Elytra slightly more than I/4 wider than prothorax, subparallel, slightly narrowed anteriorly; margin forming obtuse (nearly right), slightly dentate angles at humeri; dorsal striae formed by fine vaguely punctulate impressed lines in low spaces between intervals; latter subequal on disc, slightly raised but not costate, except 7 th strongly raised and costate basally, Ioth interval indicated posteriorly; each 3 rd interval I- or 2-punctate posteriorly, position of punctures variable. Mesosternum anteriorly and prosternal process (sometimes inconspicuously) setose. Male front tarsi moderately dilated, 3 segments squamulose below; $\sigma^{\pi}$ with $\mathrm{I}$, ㅇ 2 setae each side apex last ventral segment. Length $2 \mathrm{O}-23$; width 6.5-8.0 mm.

Holotype $\sigma^{\pi}$ (M.C.Z. Type No. 30,358) and 73 paratypes all from Kirrama Range, inland from Cardwell, North Queensland, 2000-3000 ft. altitude, Dec. 1957 and Feb. 1958, collected by the Darlingtons, in rain forest. Also the following specimens, not types: 12, mountains above (SW of) Atherton, Atherton Tableland, 300o4000 ft., Dec. 1957 and Feb. I958; I, near Black Mt., c. 20 miles north of Kuranda, probably near $2000 \mathrm{ft}$. altitude, May 1958; and 3, Mt. Lewis, near Mossman, probably near $3000 \mathrm{ft}$. , Dec. I957; all collected by the Darlingtons, in rain forest. These localities are all on the Dividing Range system, which has probably been the principal path of north-south dispersal of wet forest Carabidae in North Queensland.

$T$. frater may represent the ancestral stock, with dilated, squamulose male tarsi, from which nudipes of the Mt. Spec plateau, subvirens and simplicipes of South Queensland, and also (independently) soror of the Atherton Tableland etc. have been derived. These 5 species (including frater itself) are all allopatric and are generally similar in form and technical characters except for the differences in the $\sigma^{\pi}$ tarsi. The two following new species may be local derivatives of the same stock with $\sigma^{\pi}$ tarsi still dilated and squamulose. See map for distribution of tropical species of the frater group.

\section{Trichosternus mutatus new species}

Small; form about average for genus but rather convex; black, sometimes with faint purplish reflections; moderately shining, elytra slightly duller. Head $3 / 4$ to $4 / 5$ width prothorax; antennae rather short, scarcely extending beyond base of prothorax; eyes moderate, genae $c$. wide as eyes, rounded and narrowed to neck; 2 supra-ocular setae each side. Prothorax subcordate, I/4 ( \pm ) wider than long at middle; base equal to or slightly narrower than apex; sides broadly 
but not strongly rounded in much of length, weakly sinuate before base; basal angles $c$. right or slightly obtuse, scarcely blunted; apex subtruncate or very broadly emarginate with angles scarcely advanced, apex not margined; base subtruncate or slightly emarginate at middle, slightly rounded-oblique toward sides, weakly margined only toward angles; lateral margins narrow, scarcely wider basally, each with I seta about I/4 from apex and I on margin at basal angle; disc convex, middle line well impressed, transverse impressions rather weak; baso-lateral foveae rather weak and irregular, reaching posterior margin but separated from side margins by convex areas, not punctate and not much more rugulose than disc. Elytra slightly more than I/4 wider than prothorax, rather short, slightly narrowed anteriorly; humeral angles nearly right, slightly toothed; striae represented by depressed spaces between intervals; latter subequal on disc, convex but not much elevated except 7 th elevated and costate basally; ioth interval indicated posteriorly; each 3 rd interval with 2 or 3 dorsal punctures posteriorly. Mesosternum anteriorly and prosternal process (sometimes inconspicuously) setose. Male front tarsi moderately dilated, 3 segments squamulose; $\sigma^{7}$ with I, o 2 setae each side apex last ventral segment. Length I 8-20; width 6.5-7.0 mm.

Holotype $\sigma^{\top}$ (M.C.Z. Type No. 30,359) and 4 paratypes from Mt. Fisher (see below), c. $4000 \mathrm{ft} .$, Feb. 1958; and 5 additional paratypes from mountains above ( $\mathrm{SW}$ of) Millaa Millaa, c. $3500 \mathrm{ft}$., Dec. 1957 ; all specimens taken by the Darlingtons, in rain forest. The two localities are close together in the mountain mass between Ravenshoe and Millaa Millaa on the Atherton Tableland, North Queensland.

This species differs from the preceding one (frater) in smaller size, color, smoother basal pronotal foveae, and other details. It differs from soror in form of $\sigma^{\pi}$ tarsi, in being a little broader, different in color, and in other details. For further comments, see under following species.

Trichosternus fisheri new species

Larger than preceding; black with strong purplish reflections, moderately shining except elytra slightly duller. Head slightly more than $4 / 5$ width prothorax; eyes moderate, genae $c$. wide as eyes, rounded and narrowed to neck; antennae rather long (in genus), passing base of prothorax by 2 or 3 segments; 2 supra-ocular setae each side. Prothorax subcordate, $c$. I/4 or less wider than long at middle; base $c$. I/IO narrower than apex; apex subtruncate or very broadly emarginate, with angles scarcely advanced; apex not distinctly margined; base 
slightly emarginate at middle, faintly rounded toward sides, rather vaguely margined at sides; sides rather weakly rounded for much of length; moderately sinuate posteriorly before $c$. right, scarcely blunted basal angles; margins rather narrow, not much wider posteriorly; each with a seta about $\mathrm{I} / 3$ from apex and on margin at basal angle; disc convex, with fine middle line and weak transverse impressions; basolateral foveae deep but irregular, more or less transversely striolate; surface of disc otherwise nearly smooth, except some striae radiating from a point near base. Elytra nearly 2/5 wider than prothorax, slightly narrowed anteriorly; margin forming strong but slightly obtuse, slightly toothed angles at humeri; striae vaguely punctate in clean specimens; intervals slightly raised but not strongly costate on disc, subequal except 3 rd and 5 th slightly more prominent at base and 7th carinate especially basally; Ioth interval scarcely indicated; 3 rd interval with usually 4 to 6 punctures, irregularly spaced. Mesosternum anteriorly and prosternal process (sometimes inconspicuously) setose. Male front tarsi only slightly dilated but usually with some squamae on ist three segments (sometimes visible only on first segment - it is not clear whether they are worn off or originally missing on other segments in this case); $0^{x}$ with $\mathrm{I}$, o 2 setae each side apex last ventral segment. Length $23-25$; width $8.1-8.9 \mathrm{~mm}$.

Holotype $\sigma^{\pi}$ (M. C. Z. Type No. 30,360) and 3 paratypes from Mt. Fisher (see below), c. 4000 ft., Feb. 1958; and 2 paratypes from mountains above (SW of) Millaa Millaa, $c .3500 \mathrm{ft}$. , Dec. I957; all specimens taken by the Darlingtons, in rain forest. Both these localities are in the mountain system between Ravenshoe and Millaa Millaa, on the Atherton Tableland, North Queensland.

This species differs from the 2 preceding ones (in different ways) in details of form and color and size, in having $0^{\lambda}$ tarsi less dilated, and in having more punctures on 3 rd elytral intervals. It and mutatus appear to be confined to the same local mountain mass. Their occurrence together, localized between the ranges of frater on one side and soror on the other (see map), suggests some sort of double invasion or hybridization, although all the species in question now seem fully distinct.

\section{Trichosternus eungella new species}

Rather small, broad, depressed; black, virtually without metallic reflections, moderately shining, elytra (except marginal intervals and tops of costae) dull. Head 3/4 ( \pm ) width prothorax; eyes moderate, genae wide as or slightly wider than eyes, rounded and narrowed to neck; antennae rather long (in genus), passing base of prothorax by 
about 2 segments; 2 supra-ocular setae each side. Prothorax subcordate, $c .2 / 5$ or slightly more wider than long at middle; base slightly narrower than apex; apex broadly emarginate with angles slightly advanced, not margined; base broadly emarginate at middle subtruncate at sides; sides broadly rounded through much of length, rather strongly sinuate basally; posterior angles right or slightly acute, scarcely blunted; side margins moderate, not much broader basally, each with a seta about I/3 from apex and on margin at or very near basal angle (additional setae rarely present anteriorly); disc with well impressed middle line and anterior transverse impression, weak posterior transverse impression but large irregular baso-lateral impressions; latter strongly transversely strigulose. Elytra I/5 ( \pm ) wider than prothorax, slightly narrowed anteriorly; margin forming $c$. right (slightly obtuse) dentate angles at humeri; discal striae in clean specimens indicated by rows of rather vague punctures; even discal intervals scarcely convex, odd intervals costate; no distinct roth interval; each 3 rd interval usually 2-punctate, behind middle and on declivity. Mesosternum and prosternal process not setose. Male with front tarsi slightly dilated, 3 segments squamulose; $0^{\pi}$ with 2 or 3 , o with 3 or 4 (often asymmetrical) setae each side last ventral segment. Length $20-25$; width $7.8-8.3 \mathrm{~mm}$.

Holotype $0^{\pi}$ (M.C.Z. Type No. 30,36I) and 53 paratypes all from the Eungella Range, west of Mackay, Queensland, 2000-3000 ft. altitude, Nov. 1957, taken by the Darlingtons, in rain forest.

This is apparently related to T. wilsoni Cast. of South Queensland etc., but eungella is slightly broader and more depressed, with stronger elytral costae. For possible hybrids of this and following species, see under latter.

\section{Trichosternus mixtus new species}

Form about average for genus, but prothorax strongly cordate and elytra oval; black without metallic color, head and pronotum moderately shining, elytra duller. Head large, 4/5 width prothorax; eyes moderate, genae $c$. wide as eyes, rounded and somewhat narrowed to neck; antennae rather long, passing base of prothorax by about 2 or more segments; usually 3 supra-ocular setae each side (only 2 on right side in one specimen, 4 on both sides in another). Prothorax $c$. $2 / 5$ ( \pm ) wider than long at middle; base $c .4 / 5$ or slightly more width apex; apex strongly emarginate, angles (marginal channels) advanced in arc of emargination; apex not margined; base slightly emarginate, finely margined; sides rounded for much of length, strongly sinuate about I/ 6 of length before base, then subparallel to base; 
posterior angles right or slightly acute, scarcely blunted; side margins moderate anteriorly, slightly wider posteriorly, each with 4 to 9 setae near and before middle (at least 4 on each side in all specimens) and I seta posteriorly well before angle; disc with usual middle line, weak transverse impressions, and rather weak baso-lateral foveae separated from base by transverse elevation; foveae strongly transversely strigulose, and base longitudinally strigulose. Elytra $c$. I/4 wider than prothorax; margin forming $c$. right or slightly obtuse, dentate angles at humeri; striae in form of lines of small punctures (often obscured); even intervals scarcely elevated but intervals 3,5 , and 7 carinate, carinae of 3 and 5 not reaching base but 7 th very strongly carinate basally; no Ioth interval; each 3 rd interval 2-punctate posteriorly. Mesosternum without but prosternal process with setae (all specimens - most setae broken off in 2 specimens but vestiges visible). Male front tarsi moderately dilated, 3 segments squamulose; $\sigma^{t}$ with usually 2 or 3 , sometimes 4 (often asymmetrical), + with usually 4 , sometimes 5 setae each side last ventral segment. Length 24-29; width 8.4-9.5 mm.

Holotype $\sigma^{\pi}$ (M. C.Z. Type No. 30,362) and 23 paratypes all from Eungella Range, west of Mackay, Queensland, 2000-3000 ft., Nov. 1957, taken by the Darlingtons, in rain forest.

Superficially, mixtus is almost a miniature of cordatus but has extra supra-ocular setae, posterior pronotal setae farther from base, and a setose prosternal process. From eungella, with which it occurs, mixtus differs in form, extra supra-ocular and lateral prothoracic setae, position of posterior pronotal setae, and setose prosternal process. Most individuals of both species are unquestionably distinct. However, I have 5 specimens from the Eungella Range that have intermediate characters and that may be hybrids. They are intermediate in form; like eungella in having only 2 pairs of supra-ocular setae; intermediate in lateral pronotal setae ( 2 or 3 each side at and before middle, but with posterior setae near base); and like eungella in having prosternal process not setose. Only field study can determine the real status of these specimens.

\section{Trichosternus cordatus Chd.}

Although cordatus is primarily a South Queensland species, it extends into the tropics. It lives in drier woodland than most other members of the genus except superbus Cast. I found it at Beechmont (Queensland-New South Wales border); Benarkin; Yarraman; Biggenden ( $\mathrm{SW}$ of); near Monto (in dry scrubby woods with Pamborus 
viridis) ; and, in the tropics, at Byfield ( $\mathrm{N}$. of Yepoon) in semi-rain forest, and $c$. 40 miles S. of Mackay in good savannah woodland.

\section{Trichosternus spec new species}

Form nearly of $T$. superbus, with strongly cordate prothorax and oval elytra narrowed anteriorly; purple or purplish, not strongly shining, elytra slightly duller. Head large, slightly more than $4 / 5$ width prothorax; eyes small, genae slightly wider than eyes, subparallel anteriorly, rounded and slightly narrowed to neck ; antennae rather long, passing base of prothorax by about 2 segments; 2 supra-ocular setae each side (all specimens). Prothorax c. 2/5 or less wider than long at middle; base slightly more than $3 / 4$ width apex; apex broadly emarginate except rounded toward sides, with angles (marginal gutters) slightly advanced; apex not margined; base broadly emarginate except oblique near angles, rather vaguely margined; sides rounded through much of length, strongly sinuate before basal angles; latter right or slightly obtuse, not much blunted; lateral margins rather narrow anteriorly, broader posteriorly, each with several (usually 4 or 5) setae at and before middle and I before basal angle; disc with middle line distinct, transverse impressions weak; baso-lateral foveae rather deep but vaguely limited, with weak convexities toward lateral margins, and closely transversely strigulose, the strigulations extending onto disc across base. Elytra c. I/4 wider than prothorax, widest behind middle; forming $c$. right (slightly obtuse), slightly dentate angles at humeri; striae indicated by weakly punctate impressions; even intervals slightly convex, odd ones 3,5 , and 7 subcostate to costate on disc, 7th strongest and sharply carinate anteriorly; no Ioth interval; each 3rd interval usually 2-punctate, with punctures behind middle and on declivity. Mesosternum and prosternal process not setose. Male front tarsi slightly dilated, 3 segments squamulose. Length 24-30; width 8.5-10.3 mm.

Holotype $\sigma^{\top}$ (M.C.Z. Type No. 30,363) and 33 paratypes all from the Mt. Spec plateau (Paluma Range), c. 40 miles north of Townsville, North Queensland, 2000-3000 ft., Nov. 1957 and Feb. 1958, taken by the Darlingtons in or on the edges of rain forest.

In spite of their wide geographical separation, this species and superbus Cast. (of New South Wales) may represent one original stock. The new species resembles superbus in form, color, and many details, but differs from it in having only 2 (instead of 3 ) supraocular setae on each side and in having better defined posterior prothoracic angles. 


\section{Trichosternus setosiceps Sl.}

Sloane ( I 923, p. 23) described setosiceps from the South Johnstone River and Malanda, which are on or near the Atherton Tableland. The species is widely distributed on the Tableland, except apparently the northern part, and reaches the lower slopes of Mt. Bellenden Ker and extends south to the Kirrama Range.

This species differs from all other Trichosternus in having 2 segments of each male front tarsus squamulose.

\section{Trichosternus kirrama new species}

Form as figured (Fig. 3), large, with strongly cordate prothorax and oval elytra; black, head and prothorax moderately shining, elytra dull. Head large, 4/5 or slightly more width prothorax; eyes small, genae slightly wider than eyes, broadly rounded and narrowed posteriorly to neck; antennae rather long, passing base of prothorax by c. 2 segments; 2 or 3 supra-ocular setae each side (often asymmetrical) ; frontal foveae as usual except area between them slightly depressed and/or with longitudinal prominences outside them. Prothor$a x$ strongly cordate, nearly $\mathrm{I} / 2$ wider than long at middle; base $c$. $4 / 5$ ( \pm$)$ width of apex; apex emarginate at middle, rounded toward sides, with angles (lateral channels) advanced; apex not margined; base broadly emarginate except subtruncate near angles, rather irregular, vaguely margined; sides rounded through much of length, strongly sinuate about I 6 before base, thence subparallel to $c$. right, well defined posterior angles; lateral margins moderate anteriorly, slightly wider posteriorly, each 2 to 4 (rarely 5) setae at and before middle and one a little before base; disc with usual middle line, transverse impressions weak; baso-lateral impressions irregular, transversely strigulose, the strigulose area extending forward at sides and across base; extreme basal strigae longitudinal. Elytra I/5 or slightly more wider than prothorax; margin somewhat obtusely angulate but only vaguely toothed at humeri; striae formed by lines of small punctures; even intervals slightly convex, odd intervals 3 and 5 slightly more raised but not costate, interval 7 strongly raised, costate at base; no roth interval ; each 3rd interval 2-punctate, behind middle and on declivity. Mesosternum and prosternal process not setose. Male front tarsi moderately dilated, 3 segments squamulose; 2 or 3 (often asymmetrical) setae each side last ventral segment in both sexes. Length 30-33; width 9.9-10.6 mm.

Holotype $\sigma^{\top}$ (M.C.Z. Type No. 30,364) and I I paratypes all from Kirrama Range, near Cardwell, North Queensland, 2000-3000 ft., Dec. 1957 and Feb. I958, taken by the Darlingtons, in rain forest. In form, appearance, and some characters (near obliteration of 
humeral teeth, lowness of elytral intervals) this species approaches obscuripennis, but the arrangement of setae is very different. I do not know the real relationships of either species.

Britton, E. B.

\section{REFERENCES}

1940. The Carabidae (Coleoptera) of New Zealand, Part I, Pterostichini. Trans. R. Soc. New Zealand, 69: 473-508.

Darlington, P. J., JR.

1953. Australian carabid beetles II. Some new Pterostichini. Psyche, 60: 90-101.

1961a. Australian carabid beetles IV. List of localities, 1956-1958. Psyche, 67: 111-126.

1961b. Australian carabid beetles V. Transition of wet forest faunas from New Guinea to Tasmania. Psyche, 68: 1-24.

1961c. Australian carabid beetles VI. The tropical and some subtropical species of Pamborus, Mystropomus, and Nurus. Breviora, No. 142: 1-13.

Macleay, W.

1887. [T. obscuripennis.] Proc. Linn. Soc. New South Wales, ser. 2, 2: 220.

SLOANE, T. G.

1894. [Homalosoma, incl. Trichosternus.] Proc. Linn. Soc. New South Wales, ser. 2, 9: 417-425.

1899. [Homalosoma, incl. Trichosternus.] Proc. Linn. Soc. New South Wales, 24: 567-572.

1923. [T. setosiceps.] Proc. Linn. Soc. New South Wales, 48: 23.

TSCHITSCHÉRINE, T.

1902. [Trichosternus.] Horae Soc. Ent. Rossicae, 35 : 520-534. 

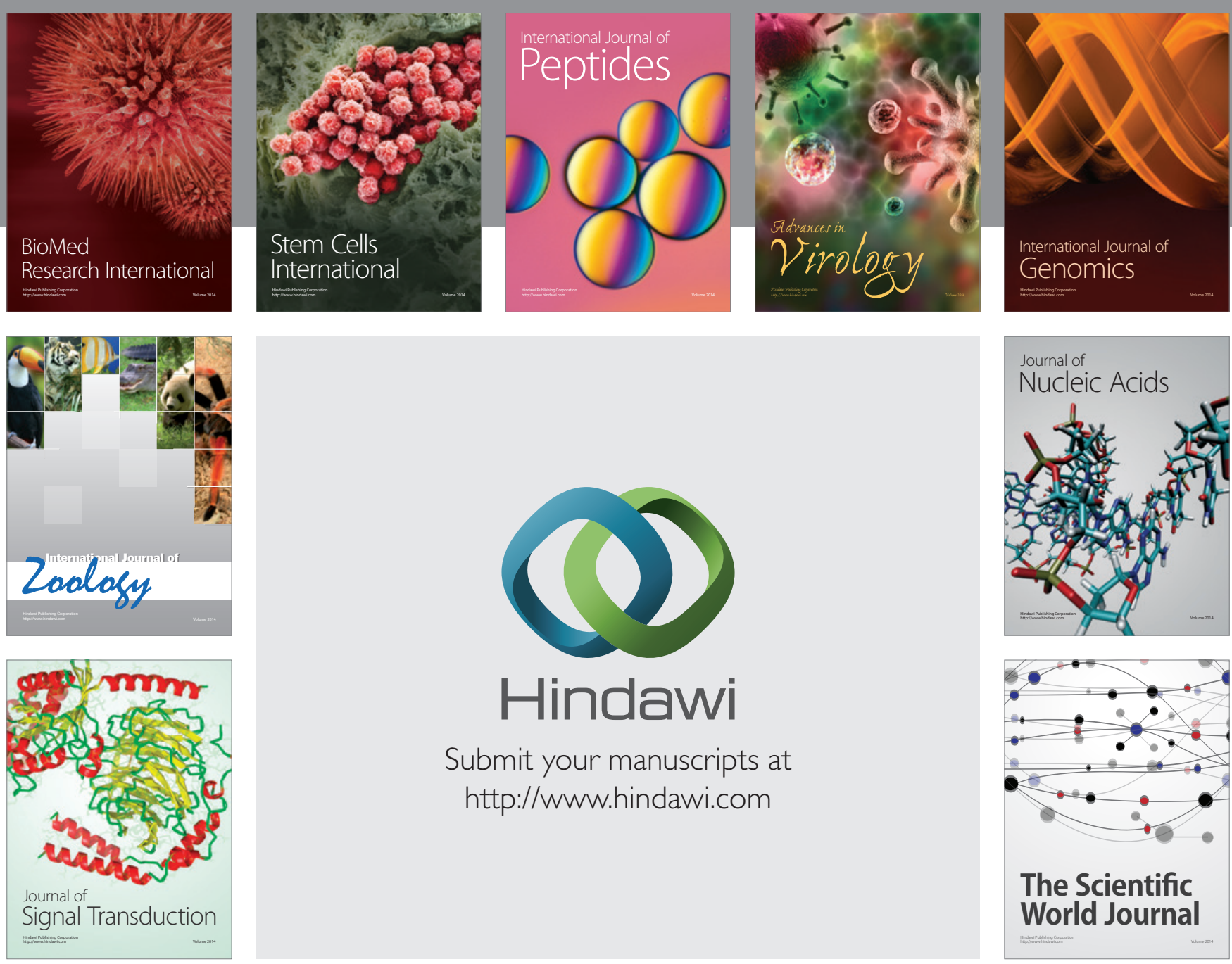

Submit your manuscripts at

http://www.hindawi.com
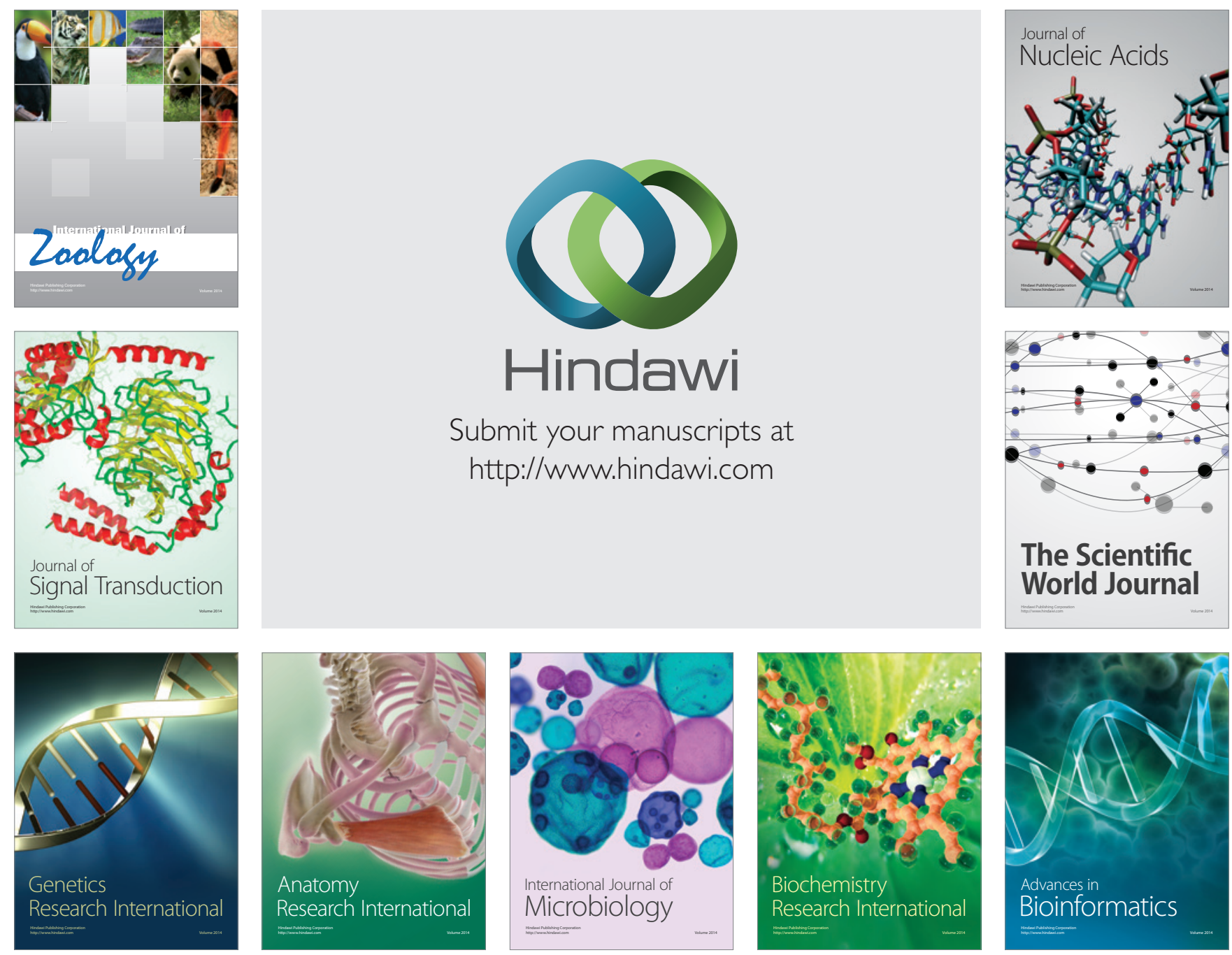

The Scientific World Journal
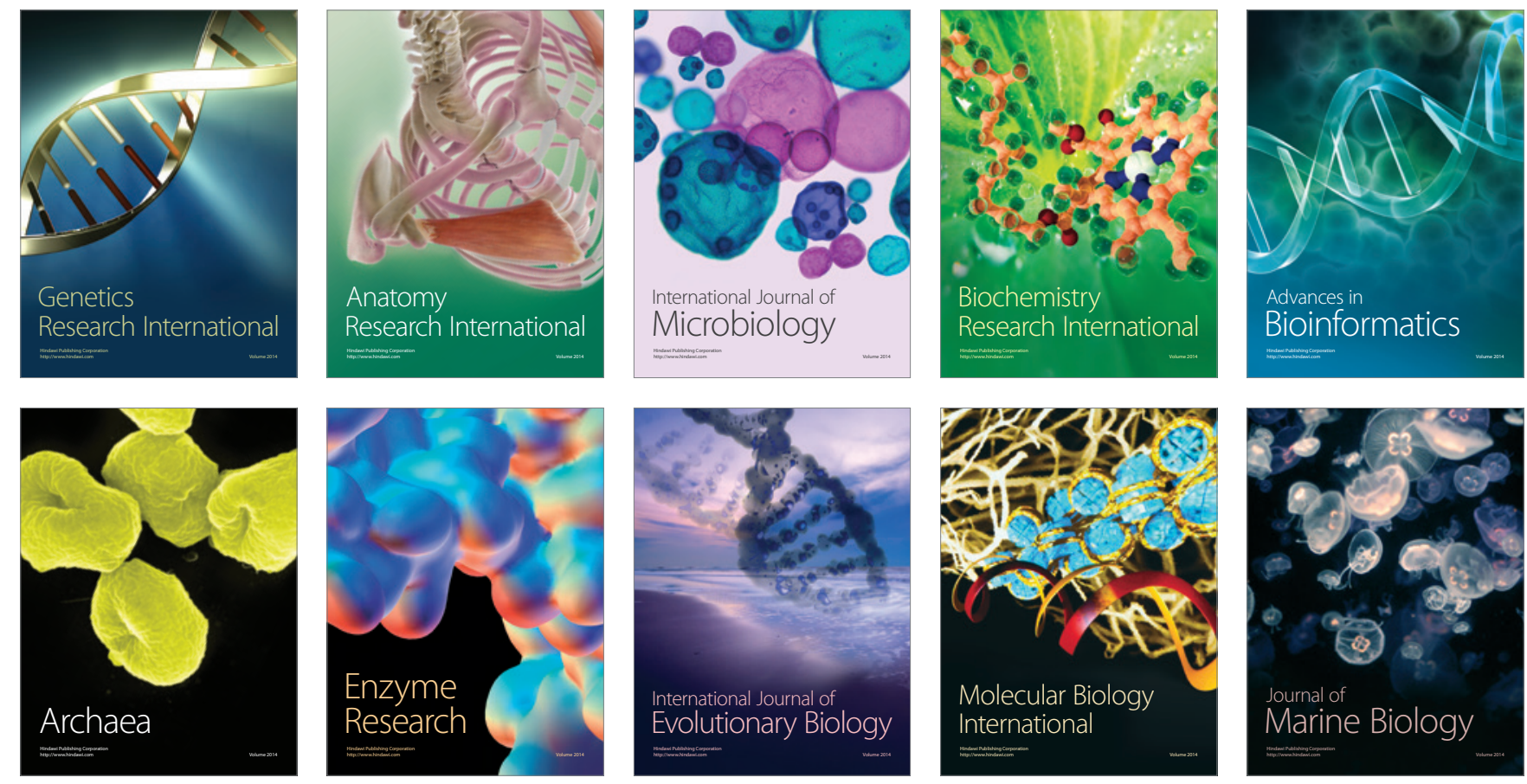